Florida State University College of Law

Scholarship Repository

Scholarly Publications

Summer 2001

\title{
Pitfalls in Partnership Law Reform: Some United States Experience
}

Donald J. Weidner

Florida State University College of Law

Follow this and additional works at: https://ir.law.fsu.edu/articles

Part of the Business Organizations Law Commons

\section{Recommended Citation}

Donald J. Weidner, Pitfalls in Partnership Law Reform: Some United States Experience, 26 J. CORP. L. 1031 (2001),

Available at: https://ir.law.fsu.edu/articles/132

This Article is brought to you for free and open access by Scholarship Repository. It has been accepted for inclusion in Scholarly Publications by an authorized administrator of Scholarship Repository. For more information, please contact efarrell@law.fsu.edu. 


\title{
Pitfalls in Partnership Law Reform: Some United States Experience
}

\author{
Donald J. Weidner ${ }^{*}$
}

I. INTRODUCTION 1031

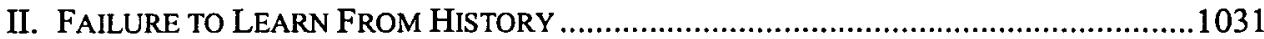

A. Dissociation and Dissolution...................................................................1031

B. Limited Liability ........................................................................................1033

C. Default Rule on Limited Liability ................................................................1035

D. At-Will Partnerships .................................................................................1036

E. Not-For-Profit Associations .......................................................................1036

F. An Unintended Consequence of Entity Theory ................................................1037

III. Failure to State Clear, Concise And Coherent Principles .........................1037

A. Fiduciary Duty and Related Rules .............................................................1038

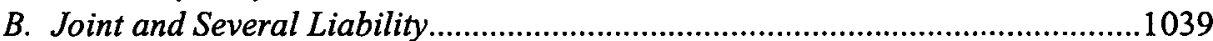

C. Failure With The Resulting Mixed Grill of Statutory Offerings .........................1040

IV. HARNESSING DIVERSE AND BALANCED EXPERTISE .............................................1042

\section{INTRODUCTION}

This article addresses major pitfalls in partnership law reform based on the Revised Uniform Partnership Act (RUPA) ${ }^{1}$ experience. The two major pitfalls are a failure to learn from history and a failure to state clear, concise, and coherent principles. The best way to avoid these pitfalls is by properly harnessing available expertise and political support.

\section{FAILURE TO LEARN FROM HISTORY}

There are numerous examples of a failure to learn from history. I begin with the " $D$ word," RUPA's most notable failure to abandon a problematic approach.

\section{A. Dissociation and Dissolution.}

Prior to the Uniform Partnership Act (UPA), ${ }^{2}$ the term "dissolution" was considered extremely confusing. The UPA, which borrowed shamelessly from the English Partnership Act of 1890 , tried to resolve the confusion in two ways. First, it defined what

* Dean and Professor, Florida State University College of Law. Dean Weidner served as the Reporter for the Revised Uniform Partnership Act from 1987-1994. The author wishes to express his appreciation to Robert W. Hillman for his helpful comments.

1. REV. UNIF. P'SHIP ACT (amended 1997), 6 U.L.A. (1995 \& Supp. 2001).

2. UNIF. P'SHIP ACT (1914), 6 U.L.A. (1995). 
dissolution was. Second, it stated what dissolution was not. Dissolution was defined as "the change in the relation of the partners caused by any partner ceasing to be associated in the carrying on as distinguished from the winding up of the business." 3 According to the statute, dissolution was not the same as termination, which did not take place until the winding up of the partnership was complete. ${ }^{4}$

Seventy-five years later, as the RUPA project was getting under way, it was clear that the term "dissolution" was still causing great confusion. For years, I submitted Drafts to the Committee without the word "dissolution." There were two basic reasons for this. First, however beautiful the initiated may have regarded the dissolution construct, it simply caused too much confusion. Second, the word itself is inapt, whether you view partnerships as aggregates or as entities. The Oxford English Dictionary defines dissolution as "separation into parts or constituent elements; reduction of any body or mass to elements or atoms; destruction of the existing condition; disintegration, decomposition."5

When a partner is being bought out, there is no "atomization" or "disintegration" of the partnership. The partnership continues, but without the departing partner. Even if a departure causes the commencement of a winding up of the business, there is no immediate atomization or disintegration. The partnership continues, but toward a new purpose, the winding up of the business. The departure simply causes a contraction in scope. The old statutory definition had the basic concept correct, but chose the wrong word to carry the message. An inadequate statutory structure was then built upon the inapt word. The structure was inadequate because it failed to clarify the distinction between buyouts and windups.

For years, the Committee worked from drafts of new breakup provisions that did not contain the "D word." The Committee drafts also contained a new structure that had separate articles for buyouts and windups. The buyout, in particular, was defined with some specificity. Near the end of the project, certain members of an American Bar Association (ABA) Business Law Section subcommittee stated that a partnership act without the word "dissolution" would be so radical that it might not receive the imprimatur of the $\mathrm{ABA}$, which in turn would make it more difficult for it to be adopted by the states. They did not want to change the new statutory structure or its new substantive rules, they simply wanted the word "dissolution" back in the statute. I was asked to add the word "dissolution" to the subsequent draft so the Committee could "see what it looks like." I added the word in such a way as to make clear that it was unnecessary. Thus, wherever the previous drafts had stated that an event caused a winding up, the next draft said that the event caused a "dissolution and winding up." I added the word "dissolution" as a obvious redundancy, so that it could easily be edited out, I thought, as soon as the scales fell from the eyes of the members of the Drafting Committee.

Not a single scale could be heard to fall. The Drafting Committee loved the new language, even though, as my fifteen-year-old daughter might say, it came from The Department of Redundancy and Needless Repetition Department. The Drafting

3. Id. § 29,6 U.L.A. $752(1995)$.

4. Id. § 30, 6 U.L.A. $756(1995)$.

5. OXFORD ENGLISH DiCTIONARY 513 (Compact ed., 1971). 
Committee thought the final product was a wonderful compromise. The statute remained as I had structured it, and as the Committee had worked with it for years (including a switchboard article on departures and separate articles on buyouts and windups) and the ABA subcommittee members had the word "dissolution" reinstated. Most importantly, RUPA sounded less radical.

It did not seem to trouble the Committee that it reinstated a word that historically had caused considerable confusion. Moreover, it added the word to a statutory structure that is very different from the UPA, and in the process, changed its meaning. Although dissolution is now limited to the commencement of a winding up, as opposed to a buyout, the statute no longer defines what dissolution is nor states what it is not.

I take some small measure of comfort from the fact that the State of Texas borrowed from our early drafts and adopted a revised partnership act that does not use the term "dissolution." 6 Despite the fact that this new act has been in force for a number of years, Professor Hamilton reports that the skies over Texas have not yet fallen. ${ }^{7}$ Nor, I hasten to concede, have the skies fallen over the now more than thirty jurisdictions that have adopted RUPA. On the other hand, needless confusion has been perpetuated by the retention of an inapt word, the meaning of which was changed without guidance or definition. As discussed below, the first revision of RUPA fell prey to this needless confusion.

\section{B. Limited Liability}

The RUPA Drafting Committee and subsequent, related law reform efforts in the United States have been remarkably squeamish about the issue of limited liability. Like Nietzsche's news of the death of God, the reality of free access to limited liability has taken quite a while to sink in. By the time the RUPA project was commissioned, limited liability was widely available through the corporate form. It was also widely available through the limited partnership form, as evidenced by the fact that billions of dollars had been raised in limited partnerships that had sole corporate general partners. The U.S. Internal Revenue Service had even come to conclude that these limited partnerships should be taxed like any other partnership.

Nevertheless, at the beginning of the RUPA project in 1987, the idea of making limited liability available to general partnerships was summarily rejected. In a memorandum I prepared for the Drafting Committee and published as an article in 1988, I noted that "the state policy in favor of imposing personal liability on a profit sharer who takes part in the control of an unincorporated business has all but vanished."8 I suggested to the Committee that a system of registration be created to provide limited liability for general partners. ${ }^{9}$ The suggestion was considered too radical, far more radical than the elimination of the word "dissolution." The Committee and the National Conference of Commissioners on Uniform State Laws (NCCUSL) kept to that opinion. Accordingly,

6. See TEX. ReV. Civ. StAT. ANN. art. 6132b, \$ 6.01 (Vemon 1994).

7. Robert W. Hamilton, Professional Partnerships in the United States, 26 J. CoRP. L. 1045 (2001).

8. Donald J. Weidner, A Perspective to Reconsider Partnership Law, 16 FLA. ST. U. L. REV. 1, 32 (1988).

9. Id. 
when RUPA was "finalized" in 1994, it contained no provisions for the limited liability of general partners.

The RUPA project failed to keep pace with external developments on limited liability. The first limited liability partnership act, offering a limited liability shield to general partners, was adopted by Texas in 1991. Large law and accounting firms that were organized as partnerships wanted to eliminate the possibility of huge personal liability for professional malpractice claims arising out of a nationwide savings and loan association crisis. Within short order, limited liability partnership (LLP) statutes were sweeping the nation. At the same time, limited liability company (LLC) statutes were also sweeping the nation. These statutes, in which the entity is a "company" and the individuals are "members," created entities that looked very much like limited partnerships without general partners. It became clear that the general partnership form might be relegated to a very minor role, along with the aggregate theory, at least for all but inadvertent partnerships, if it did not offer a limited liability shield. Accordingly, in 1996, a mere two years after RUPA was "finalized," limited liability partnership provisions were added.

The addition of LLP provisions to the rest of RUPA is not always pretty. Much is left to the Official Comments. ${ }^{10}$ Furthermore, the Official Comments are inconsistent in the way they discuss partnership continuity. For example, the Comments to Section 1001 appear to disregard RUPA's new concept of dissociation and new role for the term "dissolution" and reflect more of a UPA conception that a partnership dissolves every time a member leaves. In addition, the Comments are inconsistent with the concept, under both the UPA and RUPA, that a partnership continues only until its winding up is complete.

The statement that "a partnership that dissolves, but whose business is continued under a business continuation agreement, retains its status as a limited liability partnership without the need to refile a new statement" 11 is inconsistent with RUPA's concepts of dissociation and dissolution. Under RUPA, if a partnership continues its business pursuant to a continuation agreement, there is no dissolution. Dissolution is the commencement of a winding up. ${ }^{12}$ If the partners have contracted away the commencement of winding up when a partner departs, as they are permitted to do, ${ }^{13}$ they have contracted away dissolution.

The statement that "limited liability partnership status remains even though a partnership may be dissolved, wound up, and terminated"14 is inconsistent with the concept under both the UPA and RUPA that a partnership continues only until its winding up is complete. A partnership terminates when "the winding up of its business is completed."15 Part of the winding up is the extinguishment of the partnership's obligations. It is technically inconsistent to suggest that partnership status continues after

10. See Robert W. hillman, Allan W. Vestal \& Donald J. Weidner, The ReVised Uniform PARTNERSHIP ACT chs. 10, 11 (2000) (hereinafter HILlMAN, VESTAL \& WEIDNER).

11. REV. UNIF. P'SHIP ACT § $1001 \mathrm{cmt}$. (amended 1997), 6 U.L.A. 136-37 (Supp. 2001).

12. Id. $\$ 801,6$ U.L.A. 108 (Supp. 2001).

13. Id. $\S 103,6$ U.L.A. 44 (Supp. 2001).

14. Id. $\S 1001 \mathrm{cmt} ., 6$ U.L.A. 136-37 (Supp. 2001).

15. Id. $\S 802(\mathrm{a}), 6$ U.L.A. 113 (Supp. 2001). 
all the partnership's business has been concluded. Perhaps the inconsistency is an understandable effort to address the difficult issue of partnership termination. ${ }^{16}$

My strong recommendation for English and Continental efforts is that limited liability provisions be made a part of the core statutory undertaking. Stare the reality of limited liability in the eye and address it at the outset. Otherwise, a special limited liability SWAT team may crash into the statute at a later date and leave things a bit untidy, as SWAT teams tend to do. Much more importantly, if the partnership form cannot compete with other forms that offer limited liability, it will die on the vine. Limited liability companies have surpassed partnerships in their frequency of adoption, in part because the LLC form delivered freedom from personal liability sooner than the partnership form. In just a few years, people adopted the limited liability company, became accustomed to it, and are sticking with it. The limited liability partnership now offers just as much, but the offer came too late.

\section{Default Rule on Limited Liability}

Default rules set on unlimited personal liability reflect how the law fails to make a clean break with its history. There are two separate questions with regard to limited liability. The first is whether limited liability is available. The second is the default rule concerning limited liability. If limited liability is available by a perfunctory filing, why not reduce transaction costs and make it available without the filing? Stated differently, how formalistic will we continue to be?

A current hot issue in the United States is the default rule for general partners in limited partnerships. ${ }^{17}$ It is clear that general partners in limited partnerships can incorporate to avoid liability. It is also clear that limited partnerships can register as limited liability partnerships, thus eliminating the personal liability of the general partner. And, it is clear that the limited partnership form can be avoided entirely by using a limited liability company to obtain limited liability. Indeed, it is now also clear that the limited partnership form can be avoided by the use of a general partnership that registers as a limited liability partnership. Nevertheless, current law reform efforts are not yet at the point of prescribing a default rule of limited liability for the general partner in a limited partnership. It simply sounds too radical. The emperor may have shed most of his clothes, we are willing to say, but surely he is wearing a thong.

16. It was difficult to determine when a partnership terminated under the UPA and it continues to be a problem under RUPA. Even after all parties believe that a partnership's business has been completed, a liability may be asserted or an asset may be discovered. One way of responding is to say that the initial appearance of termination was deceptive. With respect to the liability shield, another response is to state-as the Official Comments to RUPA section 801 appear to conclude-that each partner has a shield that continues even if the partnership no longer exists.

17. See Ira Meislik, General Partner Liability, A Side-by-Side Debate, 17 PUBOGRAM (ABA Bus. Law Section, P'ship \& Unincorp. Bus. Org. Committee) No. 2, Feb. 2001, at 8. ("No proposed revision to the Revised Uniform Limited Partnership Act (RULPA) has engendered more debate than whether, by default, general partners should have limited liability for the debts and obligations of the partnership."). 


\section{At-Will Partnerships}

A fundamental purpose of RUPA was to provide stability for partnerships that have contracted for stability. Because RUPA continued traditional terminology concerning "atwill" partnerships, its definition of partnerships that have contracted for stability is unnecessarily narrow.

Under RUPA, a dissociation from an at-will partnership results in the winding up of the partnership, or, if you prefer, results in a "dissolution and winding up."18 "Partnership at will" is defined as "a partnership in which the partners have not agreed to remain partners until the expiration of a definite term or the completion of a particular undertaking."19 This definition does not embrace the full spectrum of partnerships that have contracted for stability. For example, consider a partnership agreement that provides that the partnership will continue until a majority of partners decides to the contrary. Has a "definite term" or "particular undertaking" been provided for? For further example, consider a partnership formed to continue in perpetuity. Is there a "definite term" or "particular undertaking?" If not, the partnership is "at will" and can be wound up, or "dissolved and wound up," by any partner at any time. Yet there seems to be no reason to decline to enforce a partnership agreement that states that the partnership shall continue until a majority decides otherwise. Nor does there seem to be a compelling reason to preclude an agreement for a perpetual partnership. ${ }^{20}$

\section{E. Not-For-Profit Associations}

RUPA should have been more accommodating to unincorporated associates seeking to opt into the partnership form. RUPA provides that a partnership is an "association of two or more persons to carry on a business for profit."21 The Official Comments hammer the point home to nonprofits by stating that "[a]n unincorporated nonprofit organization is not a partnership under RUPA, even if it qualifies as a business, because it is not a 'for profit' organization." 22

There is no policy reason why other associations, falling just outside the traditional definition of partnership, or falling in a gray area, should be denied the opportunity to opt into the partnership form. The State of Delaware so concluded. When it adopted RUPA in 1999, it added supplementary language to the definition of partnership that provided that "the association of two or more persons... to carry on any purpose or activity not for profit, forms a partnership when the persons intend to form a partnership." 23 If a nonprofit association can opt into the partnership form, filing as a limited liability partnership should eliminate personal liability of the associates, at least in the absence of

18. REV. UNIF. P'SHIP ACT $\S 801$ (1) (amended 1997), 6 U.L.A. 108 (Supp. 2001).

19. Id. § 101(8), 6 U.L.A. 37 (Supp. 2001).

20. See Robert W. Hillman, RUPA and Former Partners: Cutting the Gordian Knot with Continuing Partnership Entities, 58 LAW \& CONTEMP. PROBS. 7, 10-12 (1995) (contending that RUPA allows partners to create a type of at-will partnership that can survive the withdrawal of individual members).

21. REV. UNIF. P'SHIP ACT § 202(a) (amended 1997), 6 U.L.A. 56 (Supp. 2001).

22. Id. § 202 cmt. 2, 6 U.L.A. $56-57$ (Supp. 2001).

23. DEL. CODE ANN. tit. 6, § 15-202(a) (1974). 
countervailing policy external to partnership law. Make the partnership form as useful as other forms, or contribute to it becoming an endangered species.

\section{F. An Unintended Consequence of Entity Theory}

When the UPA was being drafted at the turn of the last century, an entity approach was avoided, in part, because the drafters feared that it would be accompanied by or result in a diminishment of fiduciary duties. Time proved these concerns prophetic. RUPA's move to an entity theory has been accompanied by a significant reduction in the fiduciary duties of partners.

The reduction in fiduciary duties is consonant with the new rules on suits against partnerships and partners. In short, partners have assumed a lesser status with regard to partnership obligations to third parties. ${ }^{24}$ The obligations are primarily the partnership's. The assets belong to it. The partnership and its assets should be pursued first. The partners are more like guarantors. In the case of a limited liability partnership, the partners are not even guarantors. In addition, partners are now third parties who can bring suit against the partnership and the other partners. ${ }^{25}$

Consider the impact these changes have on obligations within the partnership. What of the duties owed to partners to protect their interests in the partnership? Are not those duties now primarily those of the partnership? Are not the partners themselves now more minor players? At the very least, it is now clear that they can contract to be minor players, guarantors whose obligations are limited to the letter of their guaranty.

\section{Failure to State Clear, Concise, AND COHERENT PrinCiPles}

The second major pitfall is the failure to state clear, concise, and coherent principles. Statutes can be too long. Statutory provisions can be too complex. Throughout the RUPA drafting process, some participants believed that the drafters should attempt to answer, in the statute, every question that arose in our discussions. Although a majority of drafters were not of this view, some did appear to believe that there was little or no downside to a very lengthy statute.

The drafters of RUPA should have learned from the unfortunate experience of the tax law of partnerships. Some of the basic regulations on the taxation of partnerships and limited liability companies are hideously complex. ${ }^{26}$ Lawyers, accountants, and business people who should be able to read the regulations on partnership allocations with relative ease now do not read them at all because of their complexity. Standard form partnership, limited partnership, and limited liability company agreements contain complex, boilerplate tax language that responds to this complexity. Most lawyers dealing with these agreements will never understand their complex allocation provisions, even though these provisions direct the economic consequences of the partnership. This lack of understanding, I believe, is unhealthy for lawyers and for the clients they serve. It is also

24. REV. UNIF. P'SHIP ACT $§ 307$ (d) (amended 1997), 6 U.L.A 73 (Supp. 2001). See generally HILLMAN, VESTAL \& WEIDNER, supra note 10, at 154-57.

25. REV. UNIF. P'SHIP ACT $\S 405$ (b) (amended 1997), 6 U.L.A. 87-88 (Supp. 2001).

26. See Treas. Reg. \$1.704-1(b) (1986). 
unhealthy for the business form when an agreement among the parties becomes more like a government registration than a clear statement of the relationship.

\section{A. Fiduciary Duty and Related Rules}

The appropriateness of RUPA's policy restricting the fiduciary duties of partners has been discussed at length elsewhere. ${ }^{27}$ This section focuses on the length, complexity, and coherence of RUPA's provisions implementing this policy rather than on the policy itself.

RUPA's new rules on fiduciary duties and related obligations are much longer than similar provisions under the UPA and are dispersed throughout RUPA. ${ }^{28}$ The duty of loyalty and the obligation of good faith and fair dealing are set out in section 404 . Partnership rights and duties with respect to information are contained in section 403 . Separate mandatory minima on these rights and duties are explained in section 103(b). How these rights and duties are contracted or terminated on dissociation is discussed in section 603 .

These rules are more complex than they should be. To answer a question about a partner's duty on a breakup, and the extent to which it can be contracted away, all four sections may need to be consulted. Reading RUPA on this point is a little like reading the Internal Revenue Code when it is necessary to flip from provision to provision to get a complete statement of the applicable rule.

These rules also lack a clear statement of principle. It is not clear why certain rules are considered fiduciary and others are not. For example, it is not clear why the duty to provide information is not a fiduciary duty, ${ }^{29}$ whereas the duty to share a partnership opportunity is. ${ }^{30}$ What is the qualitative difference between a duty to share information about an opportunity and the duty to share that opportunity? This lack of a clear principle raises a broader point: the duties are stated as if they are separate, yet no "bright line" distinguishes them.

Interestingly, with all the complexity, the provision that is the clearest statement of principle has been lost in the shuffle. Early in the RUPA project, proponents of reining in fiduciary duties asserted the biggest problem with calling a partner a fiduciary was that courts were likely to require a partner to be a selfless trustee. Case law, on the other hand, recognized that there was a legitimate sphere for partners to pursue self interest. ${ }^{31}$

This basic problem was addressed in Section 404(e), which provides: "A partner does not violate a duty or obligation under this [Act] or under the partnership agreement merely because the partner's conduct furthers the partner's own interest." 32 This is a clear statement of principle that a partner need not be a disinterested trustee. Furthermore, it applies across the life of a partnership, from formation, through operation, to buyout or liquidation. It also avoids an unnecessary distinction between fiduciary duties and other obligations. Finally, it avoids drawing bright lines among fiduciary duties where none

27. For extensive citations to authority including statutory variations, see generally HILLMAN, VESTAL \& WEIDNER, supra note 10, at 200-15.

28. For an integrated discussion of these provisions, see Donald J. Weidner, Cadwalader, RUPA and Fiduciany Duty, 54 WASH. \& LEE L. REV. 877, 899-914 (1997).

29. REV. UNIF. P'SHIP ACT $\$ 403$ (amended 1997), 6 U.L.A. 81 (Supp. 2001).

30. Id. $\$ 404,6$ U.L.A. 83 (Supp. 2001).

31. See Robert W. Hillman, Private Ordering Within Partnerships, 41 U. MIAMI L. REV. 425 (1987).

32. REV. UNIF. P'SHIP ACT $§$ 404(e) (amended 1997), 6 U.L.A. 83 (Supp. 2001). 
exists. ${ }^{33}$ In short, it is a thoroughly appealing proposition that responds to a basic concern about fiduciary duty. ${ }^{34}$

Unfortunately, this rule acknowledging the legitimate pursuit of self interest is lost in the shuffle of other provisions. The larger point is that the structure of the statute matters. Physical elevation within a statute can help emphasize substance. The longer the statute, the easier it is to overlook its clear principles and provisions.

Another RUPA provision that confines the notion of a partner as a trustee has also been relatively overlooked. The UPA advanced the concept that a partnership is like a trust, and, like a trust, it continues until there is an accounting resolving that the trust purpose has been satisfied. This notion had been applied to require a formal accounting, in which all claims could be asserted, no matter how much time had passed. ${ }^{35}$ RUPA changed this.

Stated somewhat differently, there is a downside to a partner's new freedom under RUPA to sue the other partners and the partnership. Once a partner's claim accrues, limitation periods start running. The partner must use the claim or lose it. This downside is found in section $405(\mathrm{c})$, which provides that the accrual of any actions, and time limitations thereon, are governed by other law. ${ }^{36}$ RUPA also makes it clear that a "right to an accounting upon a dissolution and winding up does not revive a claim barred by law."37 The trust no longer continues until the trust purpose is satisfied. The partner is no longer a trustee.

\section{B. Joint and Several Liability}

At best, RUPA overstates the situation when it declares that "all partners are liable jointly and severally for all the obligations of the partnership unless otherwise agreed by the claimant or provided by law." 38 This declaration of joint and several liability is inconsistent with other provisions implementing RUPA's move to an entity theory.

33. See also DEL. CODE ANN. tit. 6, § 17-1101(d) (1974 \& Supp. 2000). This statute has been used as a model for other statutes, including limited liability company statutes:

To the extent that, at law or in equity, a partner or other person has duties (including fiduciary duties) and liabilities relating thereto to a limited partnership or to another partner, (1) any such partner or other person acting under a partnership agreement shall not be liable to the limited partnership or to any such other partner for the partner's or other person's good faith reliance on the provisions of such partnership agreement, and (2) the partner's or other person's duties and liabilities may be expanded or restricted by provisions in a partnership agreement.

Id. A related provision provides: "It is the policy of this chapter to give maximum effect to the principle of freedom of contract and to the enforceability of partnership agreements." Id. $\$ 17-1101$ (c).

34. Not everyone is enamored with this provision. Even though the direction of its thrust is clear, there are those who believe the magnitude of the thrust is not clear enough. See Allan W. Vestal, “. . Drawing Near the Fastness?"- The Failed United States Experiment in Unincorporated Business Entity Reform, 26 J. CORP. L. 1019 (2001). It seems appropriate to emphasize that statutes cannot be drafted to answer all questions. Moreover, fiduciary decisions under RUPA will be informed by fiduciary decisions in other substantive areas.

35. Another analogy is to a mortgagor's equity of redemption, which does not generally disappear; affirmative action must be taken to foreclose it.

36. REV. UNIF. P'SHIP ACT § 405(c) (amended 1997), 6 U.L.A. 88 (Supp. 2001).

37. Id. See Fike v. Ruger, 754 A.2d 254 (Del. Ch. 1999).

38. REV. UNIF. P'SHIP ACT $\S 306$ (a) (amended 1997), 6 U.L.A. 69 (Supp. 2001). 
Classically, a liability is "joint and several" only if the obligee has the option of suing either all the obligors or any individual obligor or group of obligors. The classic idea is that each obligor is individually liable for the entire obligation and can be pursued independently of the other obligors (double recovery by the obligee, of course, is not permitted). Under pure joint and several liability, a plaintiff may file suit against any one of the possible defendants, or any group of defendants. Thus, if a partnership obligation were a classic joint and several liability, a plaintiff could proceed directly against any partner, recover a judgment against that partner, and levy execution against that partner. There would be no requirement to join or to proceed against the partnership or any of the other partners or to seek satisfaction first out of partnership assets.

The declaration of joint and several liability collides with the provisions on postjudgment relief stating that creditors must pursue partnership assets before pursuing the separate assets of partners. ${ }^{39}$ Under RUPA, a partner's separate assets can be pursued first, but only by special contract. The partner must have agreed "that the creditor need not exhaust partnership assets." 40 The Official Comments explain that the post-judgment relief rule "respects the concept of the partnership as an entity and makes partners more in the nature of guarantors than principal debtors on every partnership debt." 41 Note the incoherence. Partners are not even principal debtors much less principal debtors who are jointly and severally liable.

As the introductory clause to the declaration of joint and several liability recognizes, ${ }^{42}$ if a partnership is a limited liability partnership, all semblance of joint and several liability vanishes. Indeed, all liability vanishes. RUPA declares that

an obligation of a partnership incurred while the partnership is a limited liability partnership... is solely the obligation of the partnership. A partner is not personally liable, directly or indirectly, by way of contribution or otherwise, for such a partnership obligation solely by reason of being or so acting as a partner. ${ }^{43}$

\section{Failure With The Resulting Mixed Grill of Statutory Offerings}

Today in the United States, there is a myriad of business forms, many of which accomplish, or can be made to accomplish, the same thing. There is no coherent rationale for the current cafeteria plan.

Relatively few of the specifics of business law reform of the past few decades seem to have registered on judges. To the extent that this is because relatively few disputes wind up in court, it is not necessarily bad. One goal of statutes that contain a more complete set of rules is to save people the expense of litigating. On the other hand, something more may be going on, something much less positive. When matters are litigated, I am not confident that all the relevant statutes will be consulted. There are too many of them, they are too different, and no one wants to spend much time on them.

39. Id. § 307(d), 6 U.L.A. 73 (Supp. 2001).

40. Id. $\$ 307(\mathrm{~d})(3), 6$ U.L.A. 73 (Supp. 2001). A creditor may also proceed directly against a partner's assets if liability is imposed on the partner by law or contract independent of the existence of the partnership.

41. Id. $\$ 307 \mathrm{cmt} .4,6$ U.L.A. 74 (Supp. 2001).

42. Id. § 306(a), 6 U.L.A. 69 (Supp. 2001).

43. REV. UNIF. P'SHIP ACT § 306(c) (amended 1997), 6 U.L.A. 69 (Supp. 2001). 
Only experienced practitioners who specialize in business matters are very familiar with them. Many judges have little or no business experience. They may have been elected or they may have been appointed because of their positions on social, not business, issues. Judges cannot be expected to spend a great deal of time learning the minutiae of business organization statutes. As many of them see it, there are simply too few cases to justify much attention, even in continuing judicial education programs.

Complexity and incoherence in statutory law may cause judges to apply a metatheory all their own, perhaps by returning to the common law of agency. Interestingly, as the American Law Institute's (ALI) Restatement of Agency project is unfolding, it has taken a very different approach to fiduciary issues than that taken in recent business law statutes designed to rein in fiduciary duties. The black-letter fiduciary duty provisions of the new Restatement of Agency are drafted almost as if the law-and-economics and freedom-of-contract movements of the past several decades never took place. It would be ironic if the individual or collective complexity or incoherence of business statutes designed to limit fiduciary duties and facilitate contracting out caused them to lose influence to the "old time religion" of the Restatement of Agency. On the other hand, it would not be surprising for courts and practitioners alike to be attracted to the Restatement's clear and more coherent statement of familiar doctrine.

The incoherence of law also affects how business law is practiced. As transactions are entered into, most practitioners do not want to spend much time choosing a form. Business law experts are likely to be familiar with each form, and within a particular jurisdiction, are likely to be familiar with that state's variation and how it differs from Delaware. But what of the general practitioner, who is often the person consulted by a start-up business? The general practitioner does not want to parse three or four statutes simply to select a business entity. The longer the statutes get, the more difficult they are to read. The more difficult they are to read, the less people will read them. Practitioners will tend to pick one form and ignore the others.

Complexity and incoherence also affect the process of law reform. I had a recent experience on a law reform project in Florida that was disconcerting. A group of lawyers participating in a continuing legal education program decided to dramatically overhaul Florida's limited liability company law. Florida had adopted the second LLC law in the nation, and it was a rough early attempt in need of major overhaul. For example, it contained default rules among members that were most inappropriate-most of them were based on members' capital accounts. I was pleased to serve on the Drafting Committee along with a number of distinguished and sophisticated attorneys. The Committee completely rewrote the statute in just a few months, over and among a handful of conference calls, and it was promptly enacted. The new statute made some important improvements, but it is also flawed in important ways.

The two principal business forms, the partnership and the corporation, each had its own constituency on the LLC project. Each constituency wanted familiar doctrine inserted into the LLC statute. Consider the ever-controversial provisions on fiduciary duties and related obligations. Real estate and estate planning specialists were most familiar and comfortable with the law of partnerships and limited partnerships. And so, when it came time to state the rules on the fiduciary duties of members in limited liability companies, they wanted RUPA's rules included in the LLC statute. On the other hand, corporate specialists were most familiar and comfortable with the law of corporations, 
and wanted corporate rules included in the LLC statute. The result was a compromise; both were added. The provisions are not coherent.

In short, RUPA protects partners from liability for breach of fiduciary duties by defining the duties narrowly and by providing that they can be contracted away. Corporate law protects managers from liability for breach of fiduciary duties by limiting shareholder remedies against managers. The new Florida LLC statute took a belt-andbraces approach by including both the partnership rules limiting duty and the corporate rules limiting remedies for breach of duty. The combination is not ideal. Each set of rules was inserted as if the other did not exist. The point is that even business law experts, who are active and dedicated enough to be influential in law reform, are exhibiting dysfunctional behavior because of the complexity and incoherence of business laws. The problem is compounded by the fact that there may be no effective structure for harnessing expertise in statutory drafting at the state level.

\section{HARNESSING DIVERSE AND BALANCED EXPERTISE}

Statutory revision is an intellectual, legal, and political process. There are two major national law reform groups in the United States: the ALI and the NCCUSL. Many of the ALI's products are restatements of doctrine announced by courts. These restatements are not drafted as statutes. They are influential to the extent they are approved by courts or expected to be followed by courts. NCCUSL's goal is to draft statutes that will, ideally, be adopted by every state legislature. Approval of these two different products comes from two different branches of government: the courts in the case of the ALI, and the legislatures in the case of NCCUSL. In the case of legislative reform, greater chance of success exists if the project passes muster with the $\mathrm{ABA}$, or at least does not incur its wrath. The $\mathrm{ABA}$, and state bar associations, can mount extremely effective lobbying efforts.

The ALI and NCCUSL (I hope I am not overstating the point to make it) take different approaches to the composition of Drafting Committees. ALI has a Reporter (sometimes with a Co-reporter or an Associate Reporter) who works closely with a group of "Advisers." The ALI Advisers generally have deep expertise in the law under review. Each project also has a larger "Members Consultative Group" to offer further advice before the project is brought to the floor. Many of these members also have deep substantive expertise in the subject of the project. NCCUSL has a Reporter (sometimes with a Co-reporter or an Associate Reporter) who works closely with a Drafting Committee to bring projects to the floor. NCCUSL sometimes has Drafting Committees with much less substantive expertise in the subject of the project than the Advisers in an ALI project. Part of the reason may be that NCCUSL's Drafting Committees are made up of Commissioners who are political appointees from the various states, rather than individuals selected for their deep substantive expertise in a particular area. This is not to say that Commissioners lack expertise, far from it. A second part of the explanation may be that NCCUSL does not always make a conscious effort to concentrate the greatest substantive expertise among its members on a Drafting Committee. An important part of being a Commissioner is to facilitate the enactment of NCCUSL products back home. The ultimate task of the Drafting Committee is to produce a statute that will be enacted by legislators throughout the country, many of whom are not even lawyers, much less 
specialists in the topic. A concept articulated to me is that a nonspecialist Committee should be pleased with the product and prepared to sing its praises. The distinctive expertise of the Drafting Committee, and of the NCCUSL oversight process, is found in what most states are not able to bring to bear on the drafting process: deep expertise in statutory drafting.

I believe it is important for the Reporter and the Drafting Committee to have deep and varied substantive expertise in the subject of the project. First, such expertise makes the task much more efficient. Less time is taken "getting up to speed." Second, it leaves the project less susceptible to outside influences. Outside interest groups typically bring great expertise to bear on a project. Because of the political nature of the process of law reform and the need for legislative approval in the case of statutory law reform, a project must address the concerns of outside interests. But it should do so from a position of strength. Furthermore, if the project drags on too long, the outside representatives may change, and so may the focus of their attention. Indeed, new representatives may feel compelled to raise new matters simply to justify their participation. The focus of the project may be needlessly diverted to revisit old issues or to tackle less important issues.

The admixture of expertise is also important. It is important that the judiciary have significant representation, even in a statutory project. Judges are often more resistant to the siren songs of the ideologue and of the special interest. Law reform, like other human activities, often suffers from a lack of broader context, including historical perspective. In this regard, I think that both judges and academics have a particular contribution to make. They often have a greater sense of history, of core concepts, and of analogous areas of the law than the practitioner embroiled in transactions or litigation. They also have an ability to place proponents of particular points on a spectrum of opinion and to more quickly identify ideologues or other partisans. On the other hand, a weakness of many academics is that they are often ideologues themselves, inexperienced in practice or not comfortable with compromise.

At the dawn of multidisciplinary practice, it is interesting that neither the accounting profession, nor the world of business or finance outside of law, tends to be represented on business law reform projects. Insights from lay business or finance people, and from business academics, may be particularly useful on a wide range of provisions. Finally, empirical research can aid law reform efforts. From soup to nuts, the RUPA project attempted to draft default rules of a sort that tend to be included in negotiated agreements. There was no empirical research to guide us, in part because empirical research on such matters is not fashionable in the legal academy or in the organized bar.

Without empirical research to guide statutory law reform projects, the insights of members of the practicing bar are critical. It is also important to include those who labor in different segments of the economy. It is they who know how the law works in action, both in the conference room and in the courtroom. My greatest pleasure and honor has been working with the men and women of the practicing bar who rise above ideology and special interest and give of their time to help make the law better for everyone. The best of this special breed should be identified and made an important part of every project. 
